\title{
Glucose initially inhibits and later stimulates blood ROS generation
}

\author{
Thomas Stief \\ Institute of Laboratory Medicine and Pathobiochemistry, Central Laboratory of the University Hospital, Marburg, Germany; \\ thstief@t-online.de
}

Received 14 November 2012; revised 16 December 2012; accepted 25 December 2012

\section{ABSTRACT}

Background: Glucose is the main substrate for the generation of NADPH, the cofactor of the oxidative burst enzyme NADPH-oxidase of blood neutrophils. Changes in blood glucose are thus expected to modify the generation of reactive oxygen species (ROS). The new blood ROS generation assay (BRGA) quantifies ROS changes induced by blood glucose concentrations as they are found in diabetes mellitus. Material and Methods: Citrated or EDTA blood of 6 healthy donors were analyzed in the BRGA: $10 \mu \mathrm{l}$ sample in black polystyrene F-microwells (Brand ${ }^{\circledR} 781608$ ) were incubated in triplicate with $125 \mu$ l Hanks' balanced salt solution, $40 \mu \mathrm{l} 0-\mathbf{2 0 0} \mathrm{mM}$ glucose in $0.9 \% \mathrm{NaCl}$ (final added conc.: 0 - $41 \mathrm{mM}$; final basal glucose conc.: about $4 \mathrm{mM}$ ), $10 \mu \mathrm{l} 5 \mathrm{mM}$ luminol, and $10 \mu \mathrm{l}$ zymosan A (final conc.: 1.9 $\mu \mathrm{g} / \mathrm{ml}$ ) in $0.9 \% \mathrm{NaCl}$. The plates were measured within $0-250 \mathrm{~min}\left(37^{\circ} \mathrm{C}\right)$ in a photons-multiplyer microtiter plate luminometer (LUmo) with an integration time of $1 \mathrm{~s}$. Results: Up to about $\mathbf{3 0} \mathrm{min}$ reaction time the mean ROS generation was $50 \%$ inhibited by about $1 \mathrm{mM}$ added glucose (= approx. IC50). At $\geq 80 \mathrm{~min}$ reaction time (possibly necessary for full phosphorylation of glucose to glucose-6-phosphate (G6P), the substrate metabolized by G6P-dehydrogenase to generate NADPH, the cofactor of the NADPH-oxidase) the mean ROS generation approximately doubled at about $1 \mathrm{mM}$ added glucose (= approx. SC200) in citrated blood. Discussion: Elevated glucose concentrations not only increase systemic thrombin generation, they can also diminish cellular fibrinolysis and increase systemic inflammation, resulting in a chronic pro-thrombotic state. The fascinating importance of NADPH-oxidases not only in phagocytes but also in the beta cells of pancreas points towards a new pathogenesis explication of diabetes mellitus type 1: whatever

\footnotetext{
*No specific funding, no conflicts of interest.
}

stimulus (e.g. a pancreas-tropic virus) could activate the beta cell's autodestructive NADPHoxidase.

Keywords: Reactive Oxygen Species; ROS; Neutrophils; Phagocytes; Blood ROS Generation Assay; BRGA; NADPH-Oxidase; Glucose

\section{INTRODUCTION}

The generation of reactive oxygen species (ROS) in blood is a very important biomarker for both innate immunology [1-3] and cellular fibrinolysis [4]. The active oxidative burst enzyme NADPH-oxidase consists of the subunits gp91PHOX/p22 PHOX in the plasma membrane, of the subunits p67 PHOX/p47 PHOX in the cytosol, and of the regulator $\mathrm{Rac} 2$; the cofactor of the enzyme is NADPH, generated by glucose metabolism $[5,6]$. Therefore, changes of the conc. of blood glucose, the precursor of glucose-6-phosphate, could well influence blood ROS generation. The aim of the present work was to find out if blood glucose concentrations that would be typical for diabetes mellitus modulate blood ROS generation.

\section{MATERIAL AND METHODS}

Citrated blood ( $4.5 \mathrm{ml}$ venous blood drawn into polypropylene monovettes containing $0.5 \mathrm{ml} 106 \mathrm{mM}$ sodium citrate; Sarstedt, Nümbrecht, Germany) or EDTA blood (2.6 $\mathrm{ml}$ venous blood drawn into polypropylene monovettes containing $1.6 \mathrm{mg} / \mathrm{ml} \mathrm{K} 3$-ethylene diamine tetra acetate (EDTA); Sarstedt) of 6 healthy donors that gave written consent after explanation were analyzed in the blood ROS generation assay (BRGA) [7,8]: $10 \mu 1$ sample in black high quality polystyrene F-microwells (Brand, Wertheim, Germany; article nr. 781608) were incubated in triplicate with $125 \mu$ l Hanks' balanced salt solution (HBSS; modified without phenol red; SAFC Biosciences-Sigma, Deisenhofen, Germany; article nr. 55037C$1000 \mathrm{ML}$ ), $40 \mu 10-200 \mathrm{mM}$ glucose in $0.9 \% \mathrm{NaCl}$ (final added concentration: 0 - $41 \mathrm{mM}$; final basal glucose concentration: about $4 \mathrm{mM}), 10 \mu 15 \mathrm{mM}$ luminol sodium salt (Sigma; article nr. A4685-1G; $1 \mathrm{~g}$ dissolved in 25.1 
$\mathrm{ml}$ resulted in a $200 \mathrm{mM}$ stem solution) in $0.9 \% \mathrm{NaCl}$, and $10 \mu \mathrm{l} 36 \mu \mathrm{g} / \mathrm{ml}$ zymosan A (ZyA; Sigma, Deisenhofen, Germany; article nr. Z-4250-1G, lot nr. 27H0495), final conc.: $1.9 \mu \mathrm{g} / \mathrm{ml}$. The plates were measured within 0 - $250 \mathrm{~min}\left(37^{\circ} \mathrm{C}\right)$ in a photons-multiplyer microtiter plate luminometer (LUmo; anthos, Krefeld, Germany) with an integration time of $1 \mathrm{~s}$. The approximate $200 \%$ stimulatory (approx. SC200) or 50\% inhibitory (approx. IC50) conc. of added glucose on oxidative blood burst were determined.

HBSS consisted of $185.4 \mathrm{mg} / 1 \mathrm{CaCl}_{2} \cdot 2 \mathrm{H}_{2} \mathrm{O}, 200 \mathrm{mg} / \mathrm{l}$ $\mathrm{MgSO}_{4} \cdot 7 \mathrm{H}_{2} \mathrm{O}, 400 \mathrm{mg} / \mathrm{l} \mathrm{KCl}, 60 \mathrm{mg} / 1 \mathrm{KH}_{2} \mathrm{PO}_{4}, 350 \mathrm{mg} / \mathrm{l}$ $\mathrm{NaHCO}_{3}, 8000 \mathrm{mg} / \mathrm{l} \mathrm{NaCl}, 90$ mg/l Na $2 \mathrm{HPO}_{4}, 1000 \mathrm{mg} / \mathrm{l}$ glucose, pH 7.0 - 7.4. Expressed in molarity, the concentrations of the HBSS components are: $1.3 \mathrm{mM} \mathrm{Ca}^{2+}, 0.8$ $\mathrm{mM} \mathrm{Mg}^{2+}, 5.8 \mathrm{mM} \mathrm{K}^{+}, 143 \mathrm{mM} \mathrm{Na}^{+}, 144 \mathrm{mM} \mathrm{Cl}^{-}, 1.6$ $\mathrm{mM} \mathrm{SO}{ }_{4}^{2-}, 0.4 \mathrm{mM} \mathrm{H} \mathrm{PO}_{4}^{-}, 0.6 \mathrm{mM} \mathrm{HPO}_{4}^{2-}, 4.2$ $\mathrm{mM} \mathrm{HCO}_{3}^{-}$, and $5.6 \mathrm{mM}$ glucose.

\section{RESULTS}

Citrated blood in the BRGA had a ROS maximum of about 1600 relative light units per second (RLU/s) obtained after about $60 \mathrm{~min}\left(37^{\circ} \mathrm{C}\right)$. Half-maximal blood ROS generation was reached at about 35 min or at about $120 \mathrm{~min}$ (Figure 1).

EDTA-blood in the BRGA had also a ROS maximum of about $1600 \mathrm{RLU} / \mathrm{s}$ after about $80 \mathrm{~min}\left(37^{\circ} \mathrm{C}\right)$, i.e. 20 min later than citrated blood. Half-maximal blood ROS generation was reached at about 50 min or at about 130 min (Figure 2).

Figures 3-12 describe individual and mean ROS generations in citrated blood:

The basal glucose concentration was about $4 \mathrm{mM}$ (final). At $17 \mathrm{~min}$ or $27 \mathrm{~min}$ reaction time $1 \mathrm{mM}$ (further) added glucose inhibited about $50 \%$ of mean ROS generation (approx. IC50 $=1 \mathrm{mM}$ added glucose) (Figures 3 and 4).

At $38 \mathrm{~min}$ or $46 \mathrm{~min}$ there appeared neither an IC50

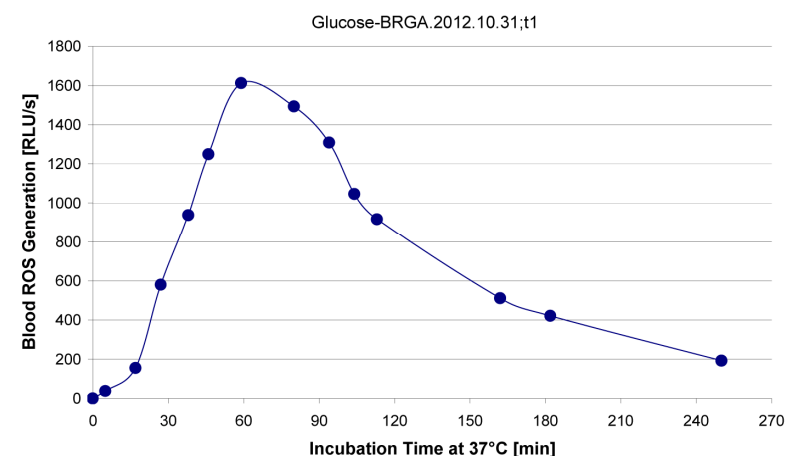

Figure 1. Normal ROS generation in citrated blood 6 normal citrated blood samples $(10 \mu 1$ each in triplicate) were analyzed in the BRGA with $1.9 \mu \mathrm{g} / \mathrm{ml}$ zymosan A stimulation. Mean values of the 6 normal samples. The inter-individual variance (SD) was about $27 \%$.

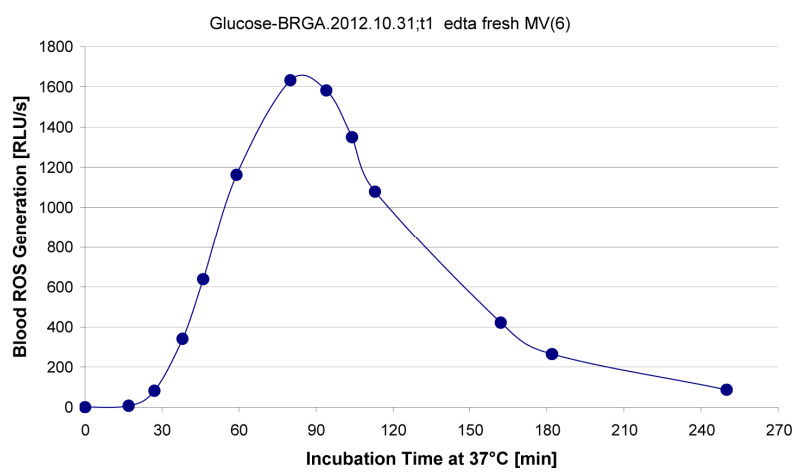

Figure 2. Normal ROS generation in EDTA blood 6 normal EDTA blood samples ( $10 \mu \mathrm{l}$ each in triplicate) were analyzed in the BRGA with $1.9 \mu \mathrm{g} / \mathrm{ml}$ zymosan A stimulation. Mean values of the 6 normal samples.

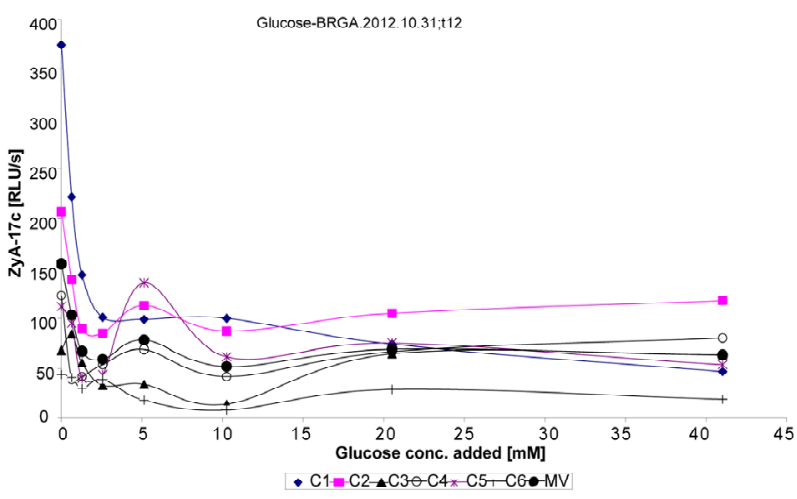

Figure 3. Blood ROS generation at $17 \min \left(37^{\circ} \mathrm{C}\right) 6$ normal citrated plasmas ( $\mathrm{C} 1$ to $\mathrm{C} 6$ ) were analyzed in the BRGA with 17 min reaction time $(\mathrm{ZyA}-17 \mathrm{c})$. Mean values of the 6 samples $(\bullet)$. Intra-assay $\mathrm{CV}$ values $<10 \%$.

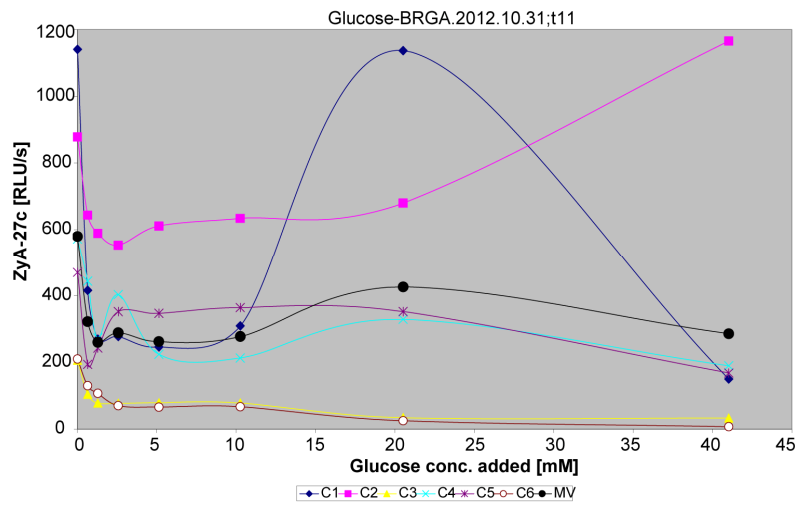

Figure 4. Blood ROS generation at $27 \min \left(37^{\circ} \mathrm{C}\right) 6$ normal citrated plasmas ( $\mathrm{C} 1$ to $\mathrm{C} 6)$ were analyzed in the BRGA with 17 min reaction time $(\mathrm{ZyA}-27 \mathrm{c})$. Mean values of the 6 samples $(\bullet)$. Intra-assay $\mathrm{CV}$ values $<10 \%$.

nor a SC200 for mean ROS generation However, 3 of 6 individual samples had approx. IC50 values of $1-2 \mathrm{mM}$ added glucose and the other 3 of 6 individual samples had SC200 values of 1 - $2 \mathrm{mM}$ added glucose (Figures 5 and 6). 
At $80 \mathrm{~min}, 94 \mathrm{~min}$, or $104 \mathrm{~min}$ the mean ROS generation nearly doubled at about $1 \mathrm{mM}$ or at about $21 \mathrm{mM}$ added glucose (Figures 7-9).

At $162 \mathrm{~min}$ or $182 \mathrm{~min}$ the approx. SC200 of mean ROS generation was $1 \mathrm{mM}$ or $11 \mathrm{mM}$ added glucose (Figures 10 and 11). A similar approx. SC200 of mean ROS generation, however at much lower RLU/s, was found for $250 \mathrm{~min}$ (Figure 12).

Figures 13-16 describe individual and mean ROS generations in EDTA blood:

At 27 min reaction time $1 \mathrm{mM}$ added glucose inhibited about $50 \%$ of mean ROS generation (approx. IC50 $=1$ $\mathrm{mM}$ added glucose) (Figure 13).

At $80 \mathrm{~min}$ or $113 \mathrm{~min}$ there appeared neither an IC50 nor a SC200 for mean ROS generation (Figures 14 and 15).

At 182 min the approx. SC200 for mean ROS generation was $21 \mathrm{mM}$ added glucose (Figure 16).

Thus, citrated blood is better than EDTA-blood to estimate changes of oxidative burst. ROS generation in EDTA-blood responded rather blunted to glucose altera-

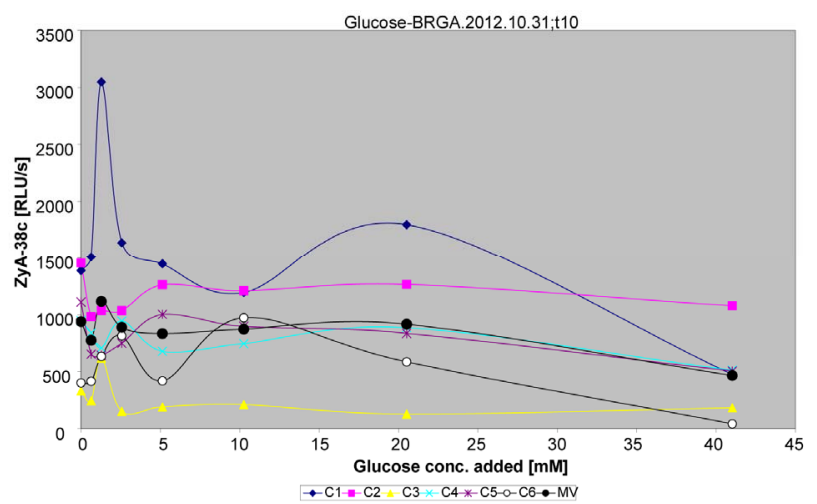

Figure 5. Blood ROS generation at $38 \min \left(37^{\circ} \mathrm{C}\right) 6$ normal citrated plasmas ( $\mathrm{C} 1$ to $\mathrm{C} 6)$ were analyzed in the BRGA with 38 min reaction time $(\mathrm{ZyA}-38 \mathrm{c})$. Mean values of the 6 samples $(\bullet)$. Intra-assay $\mathrm{CV}$ values $<10 \%$.

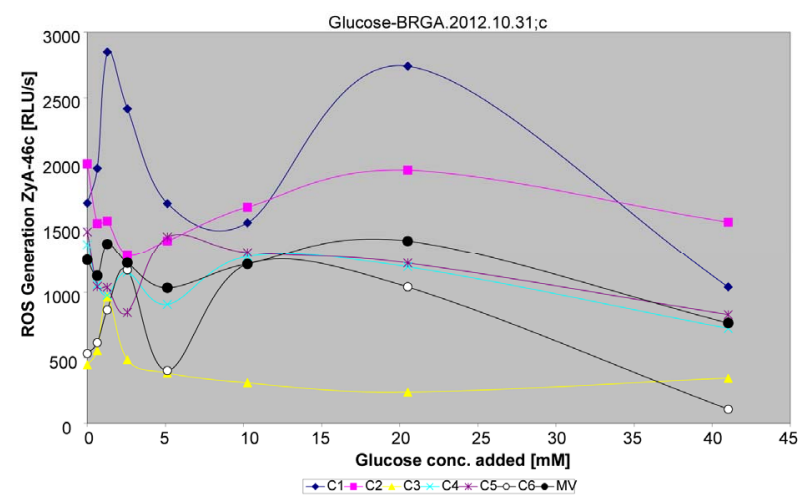

Figure 6. Blood ROS generation at $46 \mathrm{~min}\left(37^{\circ} \mathrm{C}\right) 6$ normal citrated plasmas $(\mathrm{C} 1$ to $\mathrm{C} 6)$ were analyzed in the BRGA with 46 min reaction time (ZyA-46 c). Mean values of the 6 samples $(\bullet)$. Intra-assay $\mathrm{CV}$ values $<10 \%$.

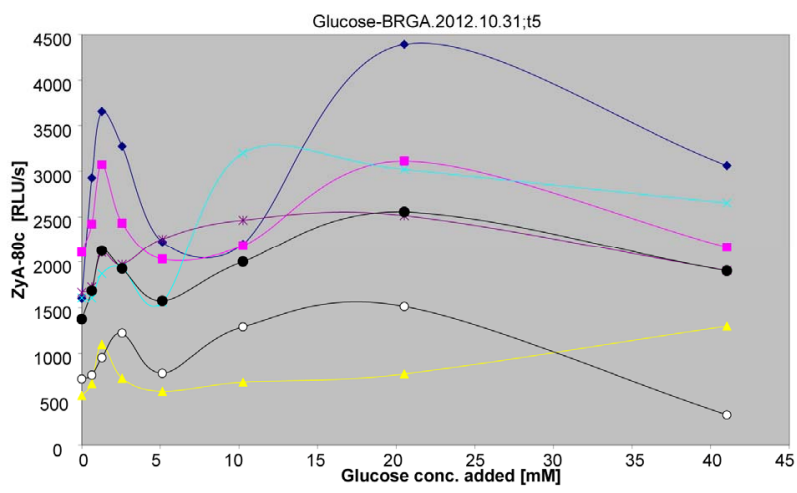

Figure 7. Blood ROS generation at $80 \mathrm{~min}\left(37^{\circ} \mathrm{C}\right) 6$ normal citrated plasmas ( $\mathrm{C} 1$ to $\mathrm{C} 6$ ) were analyzed in the BRGA with 80 min reaction time $(\mathrm{ZyA}-80 \mathrm{c})$. Mean values of the 6 samples $(\bullet)$. Intra-assay $\mathrm{CV}$ values $<10 \%$.

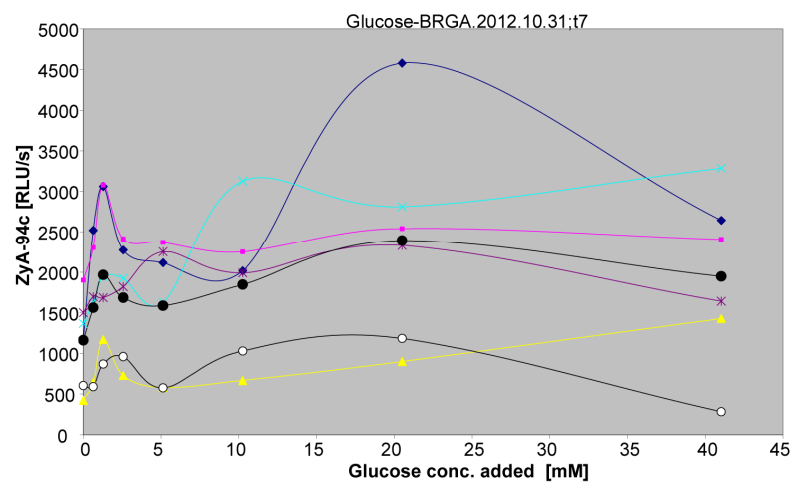

Figure 8. Blood ROS generation at $94 \min \left(37^{\circ} \mathrm{C}\right) 6$ normal citrated plasmas (C1 to $\mathrm{C} 6$ ) were analyzed in the BRGA with 94 min reaction time (ZyA-94 c). Mean values (MV) of the 6 samples $(\bullet)$, intra-assay $\mathrm{CV}$ values $<10 \%$.

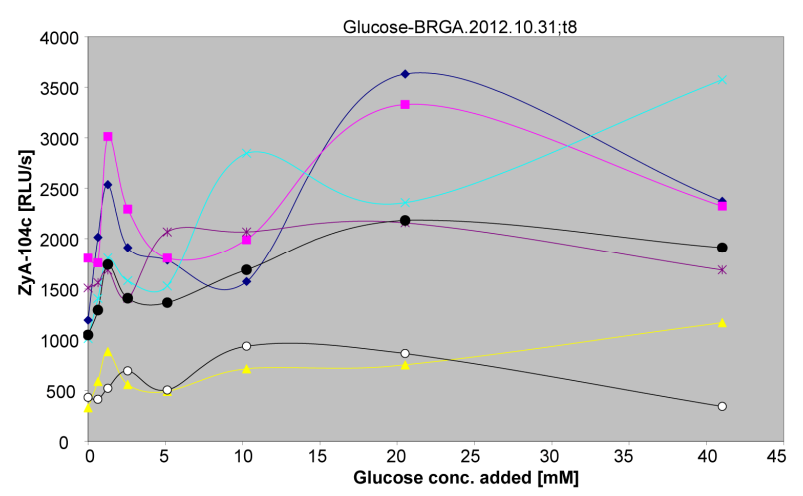

Figure 9. Blood ROS generation at $104 \min \left(37^{\circ} \mathrm{C}\right) \mathrm{C} 1$ to $\mathrm{C} 6$ plasmas were analyzed in the BRGA at 104 min (ZyA-104 c). MV (•), intra-assay CV $<10 \%$.

tions, the refined changes of ROS generation in citrated blood are demonstrated in Table 1, the reaction times of $38 \mathrm{~min}$ and $46 \mathrm{~min}$ being in the change phase from inhibition to stimulation.

$1 \mathrm{mM}$ glucose is only $20 \%$ of the normal plasma concentration of glucose that is about $5 \mathrm{mM}$. Similar to the 


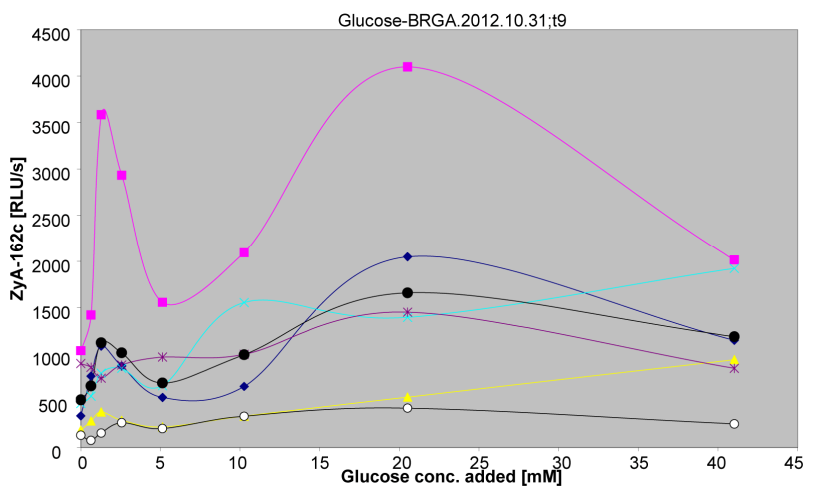

Figure 10. Blood ROS generation at $162 \min \left(37^{\circ} \mathrm{C}\right) 6$ normal citrated plasmas $(\mathrm{C} 1$ to $\mathrm{C} 6)$ were analyzed in the BRGA with 162 min reaction time (ZyA-162 c). Mean values of the 6 samples $(\bullet)$. Intra-assay CV values $<10 \%$.

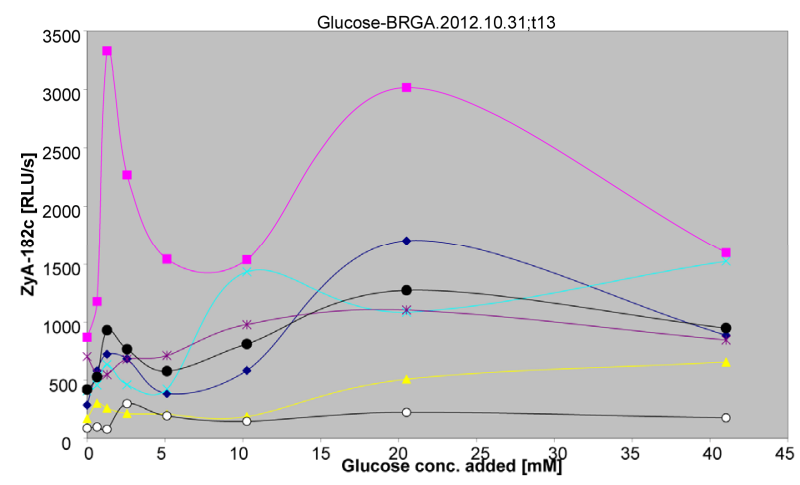

Figure 11. Blood ROS generation at $182 \min \left(37^{\circ} \mathrm{C}\right) 6$ normal citrated plasmas $(\mathrm{C} 1$ to $\mathrm{C} 6)$ were analyzed in the BRGA with 182 min reaction time (ZyA-182 c). Mean values of the 6 samples $(\bullet)$. Intra-assay $\mathrm{CV}$ values $<10 \%$.

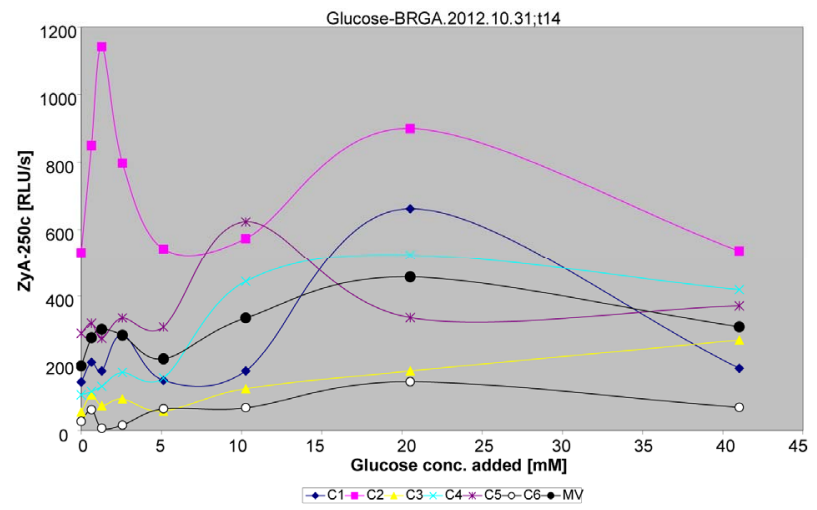

Figure 12. Blood ROS generation at $250 \mathrm{~min}\left(37^{\circ} \mathrm{C}\right) 6$ normal citrated plasmas $(\mathrm{C} 1$ to $\mathrm{C} 6)$ were analyzed in the BRGA with 250 min reaction time (ZyA-250 c). Mean values of the 6 samples $(\bullet)$. Intra-assay $\mathrm{CV}$ values $<10 \%$.

intrinsic activation of hemostasis by glucose, added glucose maximally enhanced blood ROS generation at more than one concentration [9-11], the first (and most important one) being at about $1 \mathrm{mM}$ and the second one being at $21 \mathrm{mM}$ or $11 \mathrm{mM}$, depending on the reaction time.

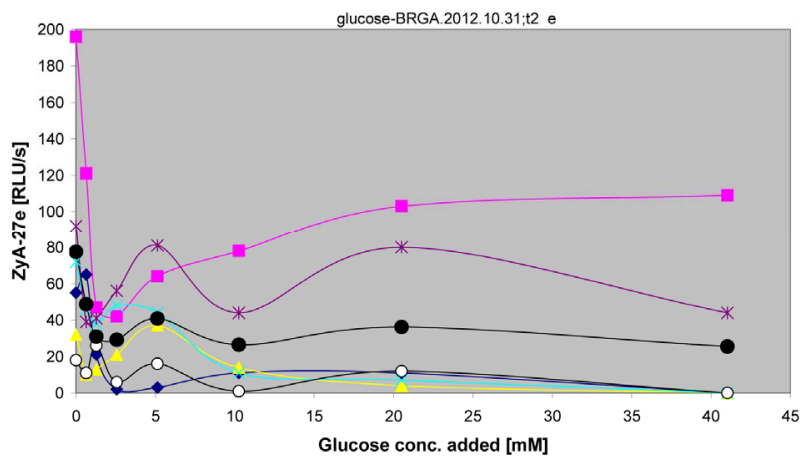

Figure 13. Blood ROS generation at $27 \min \left(37^{\circ} \mathrm{C}\right) 6$ normal EDTA plasmas (E1 to E6) were analyzed in the BRGA with 27 min reaction time $(\mathrm{ZyA}-27 \mathrm{e})$. Mean values of the 6 samples $(\bullet)$. Intra-assay $\mathrm{CV}$ values $<10 \%$.

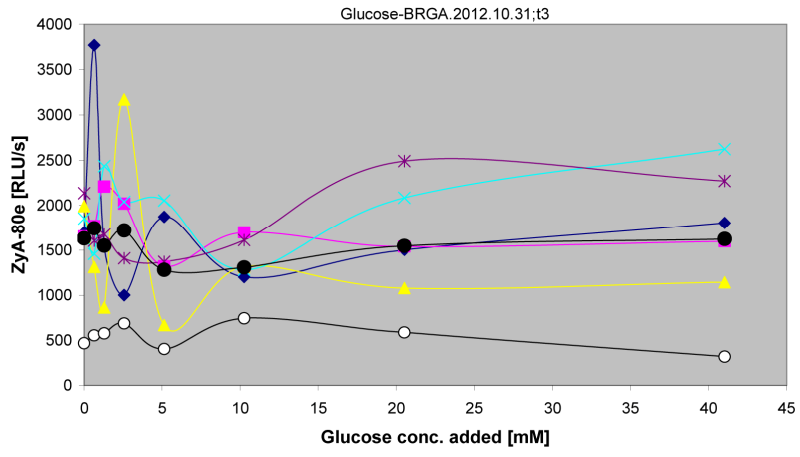

Figure 14. Blood ROS generation at $80 \mathrm{~min}\left(37^{\circ} \mathrm{C}\right) 6$ normal EDTA plasmas (E1 to E6) were analyzed in the BRGA with 80 min reaction time (ZyA-80 e). Mean values of the 6 samples (•). Intra-assay $\mathrm{CV}$ values $<10 \%$.

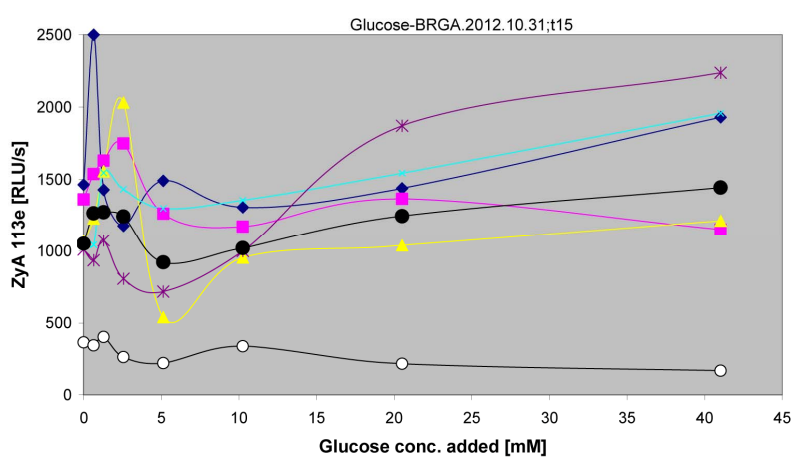

Figure 15. Blood ROS generation at $113 \mathrm{~min}\left(37^{\circ} \mathrm{C}\right) 6$ normal EDTA plasmas (E1 to E6) were analyzed in the BRGA with 113 min reaction time (ZyA-113 e). Mean values of the 6 samples $(\bullet)$. Intra-assay $\mathrm{CV}$ values $<10 \%$.

\section{DISCUSSION}

There has already been evidence that glucose can alter blood ROS generation [12-19]: $11 \mathrm{mM}$ glucose reduced the neutrophils' respiratory burst by $28 \% \pm 5 \%$ and 56 $\mathrm{mM}$ glucose by $74 \% \pm 7 \%$ [12]. $50 \%$ decreased ROS generation was detected at $25 \mathrm{mM}$ glucose [13]. Lowering 


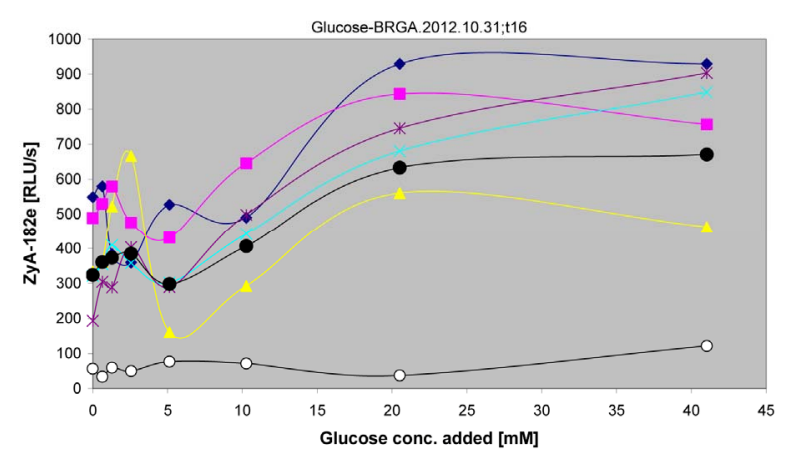

Figure 16. Blood ROS generation at $182 \min \left(37^{\circ} \mathrm{C}\right) 6$ normal EDTA plasmas (E1 to E6) were analyzed in the BRGA with 182 min reaction time (ZyA-182 e). Mean values of the 6 sam- ples $(\bullet)$. Intra-assay CV values $<10 \%$.

Table 1. Approx. IC50 or approx. SC200 values of added glucose on mean ROS generation in citrated blood.

\begin{tabular}{ccc}
\hline Reaction Time [min] & Approx. IC50 [mM] & Approx. SC200 [mM] \\
\hline 17 & 1 & - \\
27 & 1 & - \\
38 & $\ldots$ & $\ldots$ \\
46 & $\ldots$ & $\ldots$ \\
80 & - & 1 (or 21) \\
94 & - & 1 (or 21) \\
104 & - & 1 (or 21) \\
162 & - & 1 (or 11) \\
182 & - & 1 (or 11) \\
\hline
\end{tabular}

of blood glucose levels by insulin treatment of diabetic patients improved neutrophil functional activity [20].

The present work was undertaken in the new BRGA because the previous findings were not measured in whole blood that is the physiologic matrix of activated neutrophils. The main cell in blood that is competent for massive oxidative burst explosion is the neutrophil [2124] that generates about 60 fmoles $\mathrm{H}_{2} \mathrm{O}_{2}$ per $30 \mathrm{~min}$ $\left(21^{\circ} \mathrm{C}\right)$, whereas the monocyte generates less than $10 \%$ of this amount [21].

An ideal ROS detection technique should [25]:

- Imitate the physiologic ROS generation response to blood pathogens;

- Imitate the pathophysiologic blood ROS generation in autoimmunity;

- Detect globally the most important ROS of blood, that are hydrogen peroxide and singlet oxygen;

- Use a stable pathophysiologic trigger such as hydrophilic zymosan A (ZyA) [26,27];

- Be sensitive enough to detect ROS upon blood stimulation by only $1-2 \mu \mathrm{g} / \mathrm{ml} \mathrm{ZyA}$ (the approx. concentration of initial severe fungal sepsis [28]);

- Not interfere with cell function (using untoxic concentrations of the light enhancer luminol);

- Be cheap: without taxes one LUmo (microtiter plate luminometer) costs less than $€ 4500$;

- Use a close-to-physiologic buffered salt solution [29];

- Be easy to standardize;

- Dilute whole blood only 10 - 20 fold, higher dilutions result in unphysiologic matrix [30];

- Be suitable for routine measurements of hundreds of samples within minutes.

The new BRGA technique with 18 - 20 fold diluted whole blood fulfils all these requirements. This refined blood ROS test demonstrated that at incubation times less than $30 \mathrm{~min}$ a blood glucose increase of only about 1 $\mathrm{mM}$ resulted in $50 \%$ less ROS generation. Incubation times higher than 80 min resulted in $100 \%$ increased ROS generation by about $1 \mathrm{mM}$ added glucose. This time is possibly necessary for full phosphorylation in the correct cell compartment of glucose to glucose-6-phosphate (G6P), the substrate metabolized by G6P-dehydrogenase to generate NADPH, the cofactor of the NADPH-oxidase. This means that in the acute phase of blood neutrophil activation, such as the physicologic response to micro- or macro-thrombi, the diabetic patient has a decreased cellular fibrinolysis [6,31].

By contrast, in the chronic phase of neutrophil activation, the diabetic patient suffers of increased systemic inflammation [32,33]. Of particular interest is the diabetic patient in pregnancy, where increased ROS generation can threaten the health of mother and unborn [34]. Interestingly, the healthy placenta produces large quantities of the macrophage derived plasminogen activator inhibitor (PAI)-2, a suppressor of fetal rejection and autoimmunity $[35,36]$. A physiologic drug "PAI-2" could replace glucocorticoids with dangerous side reactions [37].

In conclusion, the elevated glucose concentration in diabetes mellitus not only increases systemic thrombin generation [9-11,38-40], it might also diminish cellular fibrinolysis and increase systemic inflammation [41,42], resulting in a chronic pro-thrombotic state [43].

Furthermore, the fascinating importance of NADPHoxidases not only in phagocytes but also in the beta cells of pancreas [44] points towards a totally new pathogenesis explication of diabetes mellitus type 1 [45-47]: whatever stimulus (e.g. a pancreas-tropic virus) such as mumps virus, coxsackie B, cytomegalovirus (CMV), EpsteinBarr virus (EBV) could activate the beta cell's NADPHoxidase. The generated ROS could auto-destroy the insulin producing cells $[48,49]$. Is PAI-2 a new drug against the development of type 1-diabetes mellitus [50]?

\section{ACKNOWLEDGEMENTS}

\section{REFERENCES}

[1] Bouma, G., Ancliff, P.J., Thrasher, A.J. and Burns, S.O. 
(2001) Recent advances in the understanding of genetic defects of neutrophil number and function. British Journal of haematology, 151, 312-326.

doi:10.1111/j.1365-2141.2010.08361.x

[2] Valente, S.A., Fallon Jr., W.F., Alexander, T.S., Tomas, E.R., Evancho-Chapman, M.M., Schmidt, S.P., Gorski, R., Pizov, O., DeFine, L. and Clark, A.J. (2009) Immunologic function in the elderly after injury-The neutrophil and innate immunity. Clinical and Applied Thrombosis/ Hemostasis, 67, 968-974. doi:10.1097/TA.0b013e3181b84279

[3] Cowburn, A.S., Condliffe, A.M., Farahi, N., Summers, C. and Chilvers, E.R. (2008) Advances in neutrophil boilogy: Clinical implications. Chest, 134, 606-612. doi:10.1378/chest.08-0422

[4] Stief, T.W. and Fareed, J. (2000) The antithrombotic factor singlet oxygen/light $\left({ }^{1} \mathrm{O}_{2} / \mathrm{hv}\right)$. Clinical and Applied Thrombosis/Hemostasis, 6, 22-30.

[5] Babior, B.M. (2004) NADPH oxidase. Current Opinion in Immunology, 16, 42-47. doi:10.1016/j.coi.2003.12.001

[6] Stief, T.W. (2009) Neutrophil granulocytes in hemostasis. Hemostasis Laboratory, 2, 269-289.

[7] Stief, T.W. (2013) The routine blood ROS generation assay (BRGA) triggered by typical septic concentrations of zymosan A. Hemostasis Laboratory, 6.

[8] Stief, T.W. (2013) Pathophysiologic routine blood hemostasis tests for the generation of reactive oxygen species. Hemostasis Laboratory, 6.

[9] Nielson, C.P. and Hindson, D.A. (1989) Inhibition of polymorphonuclear leukocyte respiratory burst by elevated glucose concentrations in vitro. Diabetes, 38, 1031-1035. doi:10.2337/diabetes.38.8.1031

[10] Stief, T.W. (2010) Glucose triggers thrombin generation. Hemostasis Laboratory, 3, 93-103.

[11] Stief, T.W. (2011) $\mathrm{Zn}^{2+}$, hexane, or glucose activate factor 12 and/or prekallikrein in two purified systems. Hemostasis Laboratory, 4, 409-426.

[12] Stief, T.W. (2012) Glucose activates the early phase of intrinsic coagulation. Hemostasis Laboratory, 5, 67-81.

[13] Perner, A., Nielsen, S.E. and Rask-Madsen, J. (2003) High glucose impairs superoxide production from isolated blood neutrophils. Intensive Care Medicine, 29, 642-645.

[14] Guerra, B.A. and Otton, R. (2011) Impact of the carotenoid astaxanthin on phagocytic capacity and ROS/RNS production of human neutrophils treated with free fatty acids and high glucose. International Immunopharmacology, 11, 2220- 2226.doi:10.1016/j.intimp.2011.10.004

[15] Inoguchi, T., Li, P., Umeda, F., Yu, H.Y., Kakimoto, M., Imamura, M., et al. (2000) High glucose level and free fatty acid stimulate reactive oxygen species production through protein kinase C-dependent activation of $\mathrm{NAD}(\mathrm{P}) \mathrm{H}$ oxidase in cultured vascular cells. Diabetes, 49, 19391945. doi:10.2337/diabetes.49.11.1939

[16] Omori, K., Ohira, T., Uchida, Y., Ayilavarapu, S., Batista, E.L., Yagi, M., et al. (2008) Priming of neutrophil oxidative burst in diabetes requires preassembly of the NADPH oxidase. Journal of Leukocyte Biology, 84, 292301. doi:10.1189/jlb.1207832
[17] Ayilavarapu, S., Kantarci, A., Fredman, G., Turkoglu, O., Omori, K., Liu, H., Iwata, T., Yagi, M., Hasturk, H. and Van Dyke, T.E. (2010) Diabetes-induced oxidative stress is mediated by $\mathrm{Ca}^{2+}$-independent phospholipase $\mathrm{A}_{2}$ in neutrophils. Journal of Immunology, 184, 1507-1515. doi:10.4049/jimmunol.0901219

[18] Alba-Loureiro, T.C., Hirabara, S.M., Mendonça, J.R., Curi, R. and Pithon-Curi, T.C. (2006) Diabetes causes marked changes in function and metabolism of rat neutrophils. Journal of Endocrinology, 188, 295-303. doi:10.1677/joe.1.06438

[19] Kummer, U., Zobeley, J., Brasen, J.C., Fahmy, R., Kindzelskii, A.L., Petty, A.R., Clark, A.J. and Petty, H.R. (2007) Elevated glucose concentrations promote receptor-independent activation of adherent human neutrophils: An experimental and computational approach. Biophysical Journal, 92, 2597-2607. doi:10.1529/biophysj.106.086769

[20] Alba-Loureiro, T.C., Munhoz, C.D., Martins, J.O., Cerchiaro, G.A., Scavone, C., Curi, R. and Sannomiya, P. (2007) Neutrophil function and metabolism in individuals with diabetes mellitus. Brazilian Journal of Medical and Biological Research, 40, 1037-1044. doi:10.1590/S0100-879X2006005000143

[21] Musset, B., Cherny, V.V. and DeCoursey, T.E. (2012) Strong glucose dependence of electron current in human monocytes. American Journal of Cell Physiology, 302, C286-C295.

[22] Droge, W. (2002) Free radicals in the physiological control of cell function. Physiological Review, 82, 47-95. doi:10.1152/ajpcell.00335.2011

[23] Burg, N.D. and Pillinger, M.H. (2001) The neutrophil: Function and regulation in innate and humoral immunity. Clinical Immunology, 99, 7-17. doi:10.1006/clim.2001.5007

[24] Brasen, J.C., Barington, T. and Olsen, L.F. (2010) On the mechanism of oscillations in neutophils. Biophysical Chemistry, 148, 82-92. doi:10.1016/j.bpc.2010.02.013

[25] Dahlgren, C. and Karlsson, A. (1999) Respiratory burst in human neutrophils. Journal of Immunology Methods, 232, 3-14. doi:10.1016/S0022-1759(99)00146-5

[26] Sonck, E., Stuyven, E., Goddeeris, B. and Cox, E. (2010) The effect of beta-glucans on porcine leukocytes. Veterinary Immunology and Immunopathology, 135, 199-207. doi:10.1016/j.vetimm.2009.11.014

[27] Rubin-Bejerano, I., Abeijon, C., Magnelli, P., Grisafi, P. and Fink, G.R. (2007) Phagocytosis by human neutrophils is stimulated by a unique fungal cell wall component. Cell Host Microbe, 2, 55-67. doi:10.1016/j.chom.2007.06.002

[28] Stief, T.W. and Max, M. (2008) Active endotoxin in sepsis. Hemostasis Laboratory, 1, 53-60.

[29] Freitas, M., Porto, G., Lima, J.L. and Fernandes, E. (2009) Optimization of experimental settings for the analysis of human neutrophils oxidative burst in vitro. Talanta, 78, 1476-1483. doi:10.1016/j.talanta.2009.02.050

[30] Lojek, A., Kubala, L., Cízová, H. and Cíz, M. (2002) A comparison of whole blood neutrophil chemiluminescence measured with cuvette and microtitre plate lumi- 
nometers. Luminescence, 17, 1-4. doi:10.1002/bio.664

[31] Stief, T.W. (2008) The laboratory diagnosis of the prephase of pathologic disseminated intravascular coagulation. Hemostasis Laboratory, 1, 2-20.

[32] Peluso, I., Morabito, G., Urban, L., Ioannone, F. and Serafini, M. (2012) Oxidative stress in atherosclerosis development: The central role of LDL and oxidative burst. Endocr Metab Immune Disord Drug Targets, 12, 351360.

[33] King, G.L., Ishii, H. and Koya, D. (1997) Diabetic vascular dysfunctions: A model of excessive activation of protein kinase C. Kidney International, 60, S77-S85.

[34] Petty, H.R., Kindzelskii, A.L., Chaiworapongsa, T., Petty, A.R. and Romero, R. (2005) Oxidant release is dramatically increased by elevated glucose concentrations in neutrophils from pregnant women. Journal of Maternal-Fetal and Neonatal Medicine, 18, 397-404. doi:10.1080/14767050500361679

[35] Petty, H.R., Kindzelskii, A.L., Espinoza, J. and Romero, R. (2006) Trophoblast contact deactivates human neutronphils. Journal of Immunology, 176, 3205-3214.

[36] Stief, T.W. and Kurz, J. (2012) The natural anti-inflammatory agent PAI-2 suppresses the oxidative state of human blood. Hemostasis Laboratory, 5, 145-199.

[37] Ruiz, L.M., Bedoya, G., Salazar, J., García de, O.D. and Patiño, P.J. (2002) Dexamethasone inhibits apoptosis of human neutrophils induced by reactive oxygen species. Inflammation, 26, 215-222. doi:10.1023/A:1019714618068

[38] Stief, T.W. and Mohrez, M. (2012) Glucose activates human intrinsic coagulation in vivo. Hemostasis Laboratory, 5, 83-89.

[39] Stief, T.W. (2012) The maximal plasma concentration of (delta-)negatively charged contact triggers influences plasmatic thrombin generation. In: Stief, T., Ed., Thrombin: Function and Pathophysiology. NOVA Science Publishers, New York, 37-46.

[40] Mohrez, M., Harb, H., Spies, A., Renz, H. and Stief, T.W. (2012) Systemic thrombin generation by glucose. Journal of Diabetes Mellitus, 2, 47-51. doi: $10.4236 / \mathrm{jdm} .2012 .21008$
[41] Sasaki, S. and Inoguchi, T. (2012) The role of oxidative stress in the pathogenesis of diabetic vascular complications. Diabetes-Metabolism Journal, 36, 255-261. doi:10.4093/dmj.2012.36.4.255

[42] Hadi, H.A. and Suwaidi, J.A. (2007) Endothelial dysfunction in diabetes mellitus. Vascular Health Risk Management, 3, 853-876.

[43] Stief, T.W. (2012) Thrombin-applied clinical biochemisttry of the main factor of coagulation. In: Stief, T., Ed., Thrombin: Function and Pathophysiology, Nova Science Publishers, New York, vii-xx.

https://www.novapublishers.com/catalog/product_info.ph p?products id $=33386$

[44] Oliveira, H.R., Verlengia, R., Carvalho, C.R., Britto, L.R., Curi, R. and Carpinelli, A.R. (2003) Pancreatic beta-cells express phagocyte-like NAD(P)H oxidase. Diabetes, 52, 1457-1463. doi:10.2337/diabetes.52.6.1457

[45] Mena, I., Fischer, C., Gebhard, J.R., Perry, C.M., Harkins, S. and Whitton, J.L. (2000) Coxsackie virus infection of the pancreas: Evaluation of receptor expression, pathogenesis, and immunopathology. Virology, 271, 276-288. doi:10.1006/viro.2000.0332

[46] Vanlioglu, B. and Chua, T.C. (2011) Presentation of mumps infection as acute pancreatitis without parotitis. Pancreas, 40, 167-168. doi:10.1097/MPA.0b013e3181eabd3c

[47] Jun, H.S. and Yoon, J.W. (2003) A new look at viruses in type 1 diabetes. Diabetes/Metabolism Research and Reviews, 19, 8-31. doi:10.1002/dmrr.337

[48] Briviba, K., Klotz, L.O. and Sies, H. (1997) Toxic and signaling effects of photochemically or chemically generated singlet oxygen in biological systems. Biological Chemistry, 378, 1259-1265.

[49] Nathan, C. (2006) Neutrophils and immunity: Challenges and opportunities. Nature Reviews Immunology, 6, 173182. doi: $10.1038 /$ nri1785

[50] Wu, L., Nicholson, W., Knobel, S.M., Steffner, R.J., May, J.M., Piston, D.W. and Powers, A.C. (2004) Oxidative stress is a mediator of glucose toxicity in insulin-secreting pancreatic islet cell lines. Journal of Biological Chemistry, 279, 12126-12134. doi:10.1074/jbc.M307097200 